Ann. Zootech., 1980, 29, nº h. s., 351-362.

\title{
Simple methods to predict feeding value: applied aspects
}

\author{
C. DEMARQUILLY*, M. CHENOST* and D. SAUVANT** \\ *Laboratoire des Aliments, \\ Centre de Recherches de Clermont-Ferrand, I.N.R.A., \\ Theix, 63110 Beaumont (France) \\ **Chaire de Zootechnie, INA, Paris-Grignon, \\ 16, rue Claude-Bernard, \\ 75231 Paris Cedex 05 (France)
}

\begin{abstract}
In most cases, the energy and nitrogen values of feed may be predicted with reasonable accuracy for practical needs, from the values listed in the "Feed Tables". With regard to forages, however, these Tables should be established according to the stage of growth (1st cycle) or to the age (regrowth) of the forage.

Chemical analysis may also be resorted to. The digestible crude protein content of forages and of concentrated feeds can be predicted very accurately from the crude protein content. The digestibility of organic matter or, directly, of the energy value of forages may be predicted satisfactorily from the ash, crude fibre and crude protein contents, as long as specific prediction equations that have been set up by cycle, and by forage type, are used. The energy value of compound concentrate feeds can also be predicted accurately by simple analytical criteria, unless the compound contain large amounts of ingredients with very digestible fibre (beet pulp, soyabean - hulls...). However, predicting the energy value of certain forages (mixed or complex flora forages) and of compound feeds rich in digestible fibre, from simple analytical criteria, still remains far from accurate.
\end{abstract}

\section{Résumé}

\section{Méthodes simples de prévision de la valeur alimentaire : aspects pratiques}

Dans la majorité des cas, les valeurs énergétique et azotée des aliments peuvent être prévues avec une précision accptable pour les besoins de la pratique à partir des valeurs données dans les «Tables de la valeur nutritive des aliments ». Dans le cas des fourrages ces Tables doivent cependant être établies en fonction du stade de végétation ( $1^{\text {er }}$ cycle) ou de l'âge (repousses) des fourrages.

On peut aussi avoir recours à l'analyse chimique. La teneur en matières azotées digestibles des fourrages et des aliments concentrés peut être estimée de façon très précise à partir de la teneur en matière azotées totales. La digestibilité de la matière organique ou directement la valeur énergétique des fourrages peut être prévue de façon très satisfaisante à 
partir de la teneur en cendres, en cellulose brute et en azote dans la mesure où on utilise des équations de prédiction spécifiques, établies par espèce, par cycle et par type de fourrage. La valeur énergétique des aliments concentrés peut aussi être prévue de façon précise par des critères analytiques simples sauf si les aliments composés contiennent des proportions importantes d'aliments à «cellulose très digestible» (pulpes de betterave, téguments de soja...). En revanche la prévision, à partir de critères analytiques simples, de la valeur énergétique de certains fourrages (fourrages de mélange ou à flore complexe) et des aliments composés riches en "cellulose digestible » reste peu précise.

\section{Introduction}

The nutritional requirements of animals are covered by two large categories of products :

1) Coarse feed, notably forages. The chemical composition of forages, their nutritive value, their ingestibility (amount ingested by animals fed ad libitum), may vary greatly, according to the growth stage, cycle number, species, place of cultivation and conservation method.

2) So-called concentrated feed, with high energy (cereal grains...) or nitrogen content (cakes...). With the exception of by-products, the nutritive value of a well defined concentrated feed (barley, soyabean-oil meal 50...) is generally not very variable.

The chemical composition and nutritive value of feedstuffs, as well as the amounts which animals can ingest, must be well known if rations are to be adapted to requirements, ingestion capacity and animal tastes, at the least possible cost.

We shall review the various methods of assessing the nutritive value of feeds; only those methods at present available for practical application will be considered.

\section{A. - Forages}

\section{1. - Utilisation of Feed Tables}

Digestibility of organic matter, and therefore the energy value of a given species, depends almost exclusively on its stage of development, as far as the first growth cycle is concerned (Figure 1) or on its age, in days, at regrowth. The variety and year (DEMARQUILLY and JARRIGE, 1971) and fertilisation have no great influence on the digestibility of a species at a given stage of growth. The same is true for the site of cultivation unless climatic conditions in summer are very different. Thus, Italian ryegrass and sainfoin regrowths obtained under irrigation, at Montpellier (in the Herault), are less digestible (REYNE and GaramBoIS, 1977) than those we studied at Jouy-en-Josas (Seine-et-Oise), at the Pinau-Haras (Orne) and at Theix (Puy-de-Dôme), which confirms the depressive 
influence of temperature and evaporation on forage digestibility (DEINUM et al., 1968 ; Minson and McLeOD, 1970). Thus, from the many measurements of chemical composition and digestibility carried out in the INRA a Feeds Laboratory "( 1200 green forages, 550 hay, 100 dehydrated forage, 350 grasses and legumes silages, 120 maize silages) it was possible to prepare the " Tableaux de la valeur alimentaire des fourrages " (" Tables of forage feed value ") (Feed Tables) proposed by DemarquiLly and Weiss (1970).

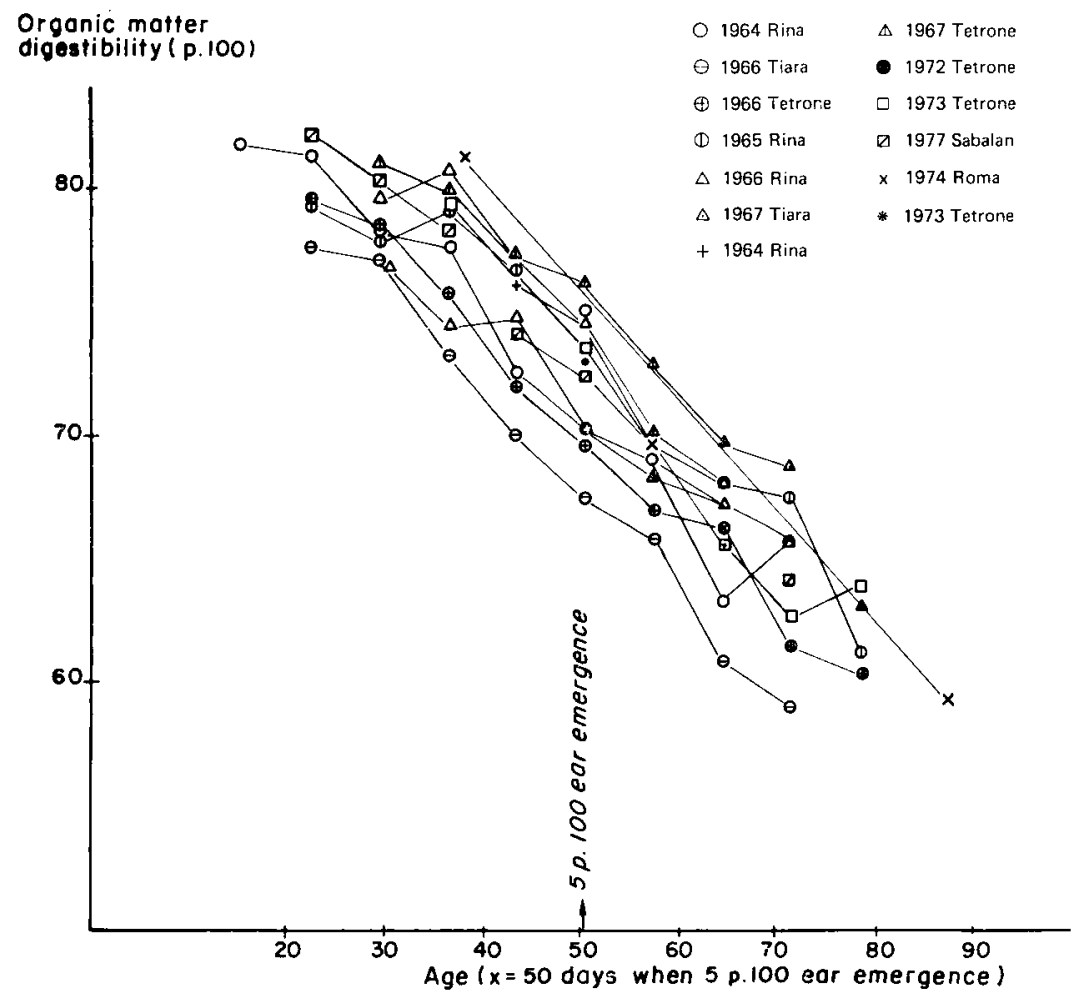

FIG. 1. - Relationships between organic matter digestibility of Italian rye-grass and stage of growth during lst cycle.

These Tables are at present being updated, but some extracts may he found in the book " L'Alimentation des Ruminants " ("Ruminant Feeding ") (INRA, 1978) or in the extension brochure " Pratique de l'alimentation de la vache laitière "( ( Feeding practices for dairy cows "). The Feed Tables list the chemical composition, nutritive value and quantities of forage ingested by sheep at the main stages of utilisation, either as green forage or as conserved forages. In most cases, they allow the digestibility of organic matter (and, therefore, their energy value) to be assessed for green, dehydrated or ensiled forages, with enough accuracy (standard deviation $\leqslant 2.5$ points) at least for forages of which the stage or age correspond to those mentioned in the Tables.

The digestibility and energy value of hays is, however, predicted with less accuracy in view of the importance and variability of losses during harvest and conservation. On the other hand, total nitrogen content, and through this, 
DCP and PDI (proteins digestible in the small intestine) as well as dry matter content and mineral content given in the Tables should be considered as an order of magnitude, because these factors may be very variable according to the type of soil, the year, the kind and extent of fertilisation, climatic conditions etc. Thus, the mineral and nitrogen contents should be determined every year, by chemical analysis of an adequate number of samples that would be representative and well-selected from among the main forages grown in every type of small natural area.

Nonetheless, predicting the nutritive value of forages from these Tables, presupposes knowing the stage of growth or age of the forages. If the latter was not observed at harvest, it is often difficult to determine it for the conserved forage. Some forages (from complex, mixed meadows, some natural pastures) are not included in the Tables and it is, therefore, necessary to resort to laboratory methods of prediction, notably to chemical analysis. However, the latter does allow a greater or lesser degree of accuracy in the prediction to be made, according to the values sought.

\section{2. - Chemical methods of predicting nutritive value}

\section{a) Predicting nitrogen value}

Very close linear relationships exist between the digestible crude protein content (DCP) and the crude protein content (CP) of feeds. For forages, many equations have been published.

Nevertheless, there are significant differences linked to the family, species, cycle number, harvest and conservation methods, etc. as shown by the equations presented in Table 1 for green grasses, legumes and grass-based natural pastures. If these differences are taken into account, the DCP content of the fresh or conserved forages can be predicted very accurately from the CP content (standard deviation of regression $\leqslant 6 \mathrm{~g} / \mathrm{kg}$ organic matter). As already emphasised it

TABLE 1

RELATIONSHIPS BETWEEN DIGESTIBLE CRUDE PROTEIN CONTENT (DCP IN $\mathrm{g} / \mathrm{kg}$ ORGANIC MATTER), AND CRUDE PROTEIN CONTENT (CP IN $\mathrm{g} / \mathrm{kg}$ OM), OF FORAGES - GREEN FORAGES FROM NATURAL PASTURE, GRASSES AND LEGUMES .

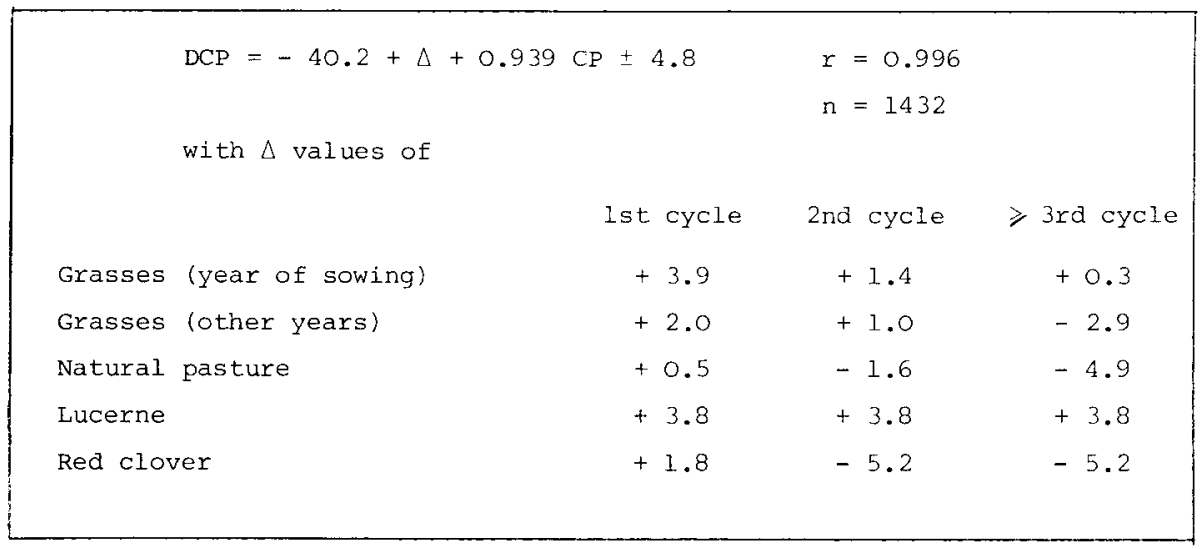


will be necessary to determine the CP levels of the main forages for each small natural area for each year, and on an adequate number of representative samples. The predictions are slightly less accurate for certain heat-damaged forages (haylages, hays baled too wet, dehydrated forages) but the decrease in the digestibility of nitrogen, caused by heat, is generally compensated for by an increase in the proportion of feed proteins that escape degradation in the rumen, so that it need not be taken into consideration.

In France, feed nitrogen value is also expressed as digestible protein in the small intestine (PDI) which can also be predicted satisfactorily (standard deviation $\leqslant 4 \mathrm{~g} / \mathrm{kg} \mathrm{OM}$ ) from the nitrogen content of forages and from nitrogen solubility. With silages, solubility is very variable from one silage to another, so it should be measured each time (cf. Demarquilly et al., 1980). On the other hand, for other forages, it is sufficient to take the mean solubilities given by DEMarquilly et al. (1978).

\section{b) Predicting energy value}

Simple chemical parameters, such as crude fibre content, notably if associated with crude protein content, allow the organic matter digestibility of forages to be predicted satisfactorily, provided that the regression equations be established according to species and to cycle. The standard deviation of regression is almost of the same order of magnitude as that obtained with age, but the closest relationships are those obtained by taking into account both age and chemical composition (cf. Table 2). Equations can be used to predict organic matter digestibility, for example of Italian ryegrass from both the crude fibre and the crude protein content, as shown in Table 3 . In the Feed Tables presently being prepared the same kind of equation will also allow the direct prediction of energy values $(*)$ expressed in UFL (milk feed unit) and UFV (meat feed unit) of all fresh and conserved forages. It is noteworthy that relationship between digestibility and crude fibre differs from one species to another (Figure 2), and from one cycle to another and, therefore, that the utilisation of one equation alone for all the first cycle grasses necessarily gives less predictions accuracy. The prediction should also be noted as less good for preserved forages than for fresh forages, firstly because the amount of available data does not make it possible to set up equations by species and by cycle, and also, because the very variable modifications undergone by the forage during harvest and conservation are such that the same chemical composition can correspond to different cutting times and therefore, invariably, to different digestibilities. This is why we recommend that the energy value of silage be calculated from the composition of fresh forage (at the time it is put into the silo). As ensiling modifies the energy value very little or not at all, the prediction is more accurate than when based on the silage composition and this method allows the energy value of silage to be known even before opening the silo.

Unfortunately, these Feed Tables do not solve the problem of predicting the energy value of mixtures or of forages produced by certain natural grasslands. For these forages, only one average equation can be used, and the prediction is mediocre (at a minimum of \pm 5 to 6 points of digestibility). In addition, for these forages it is essential to be able to use methods that allow the energy value to be predicted by the same equation or almost the same, whatever the type or

(*) The method of calculation of these values are presented in the Appendix 1 . 


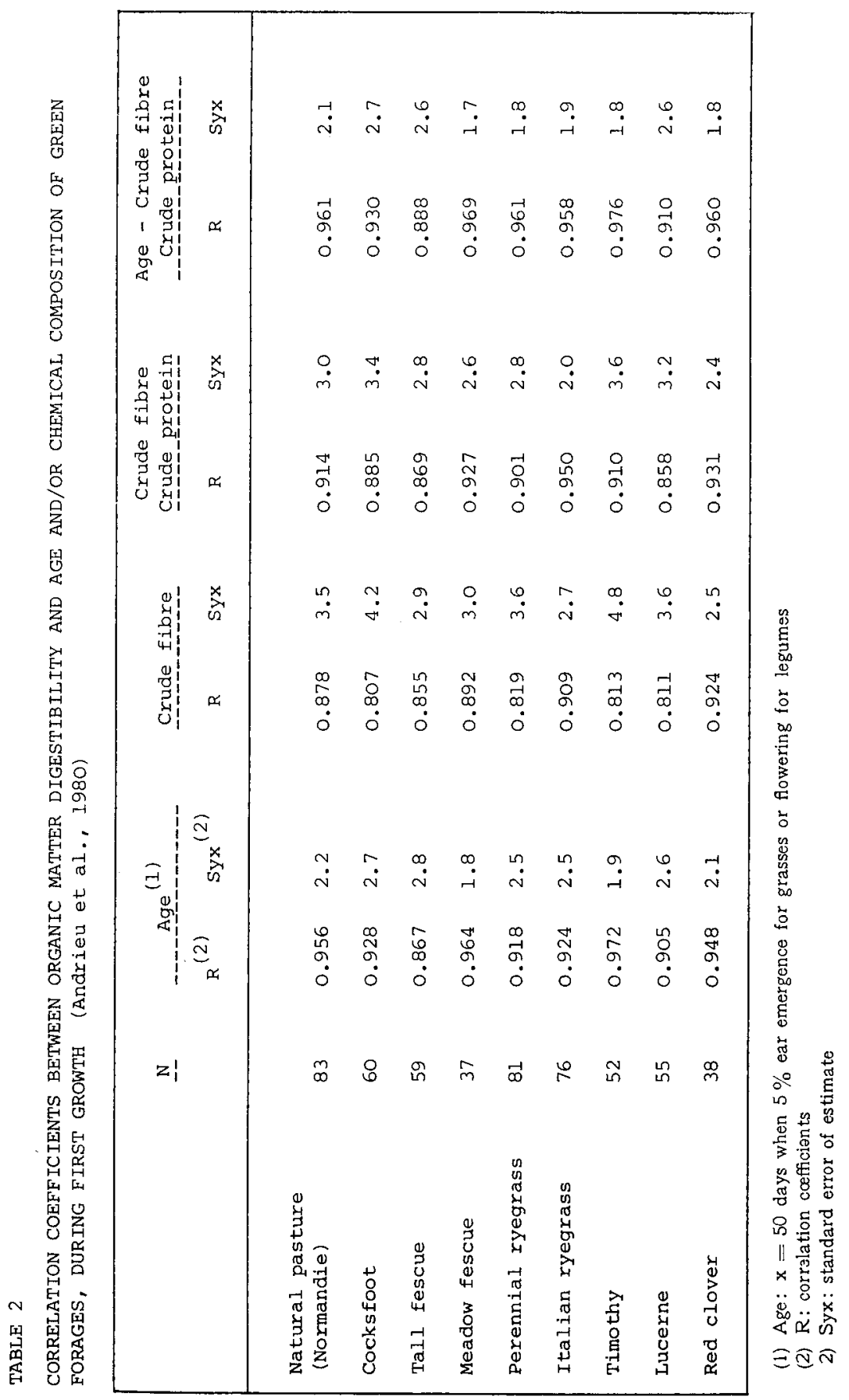




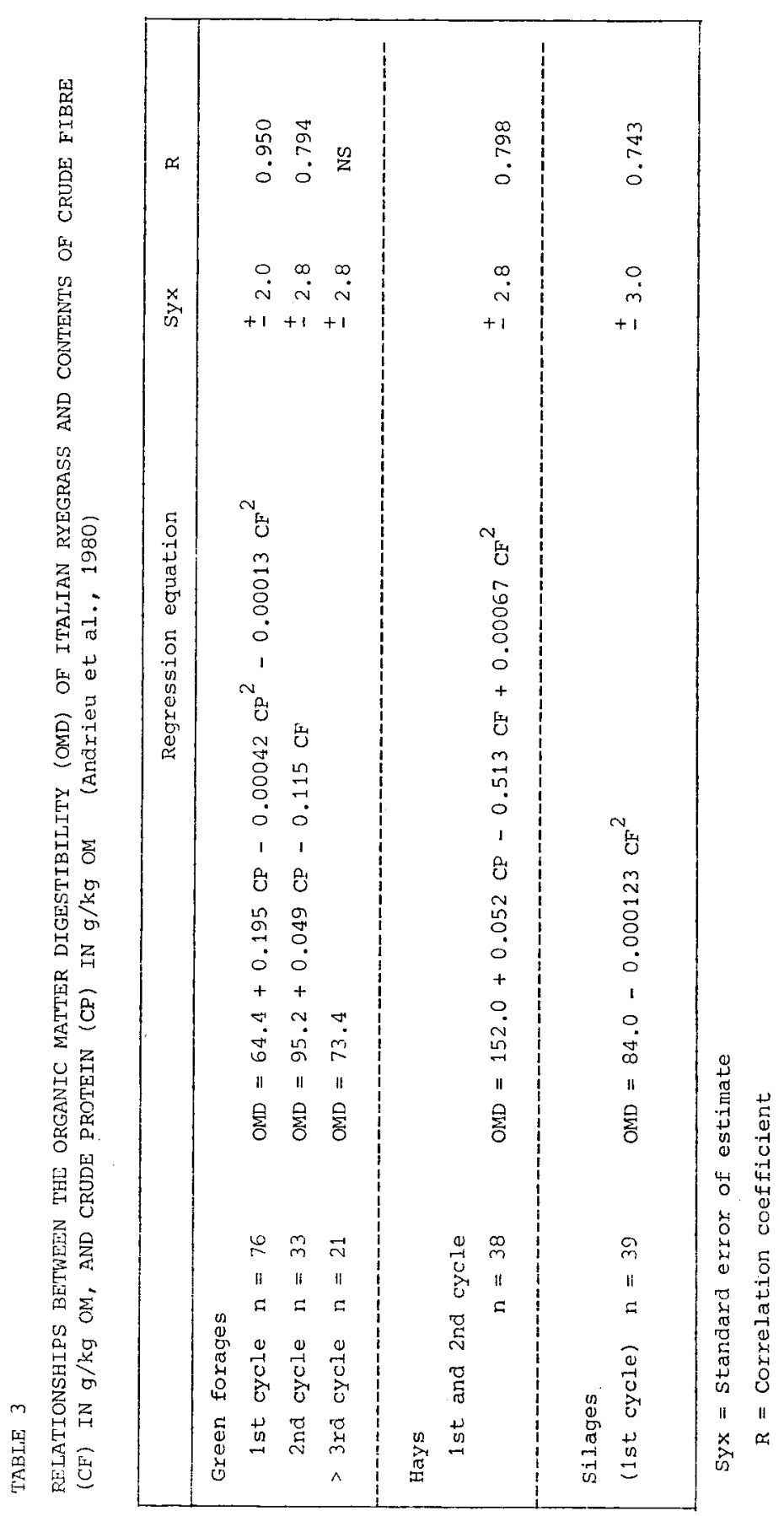




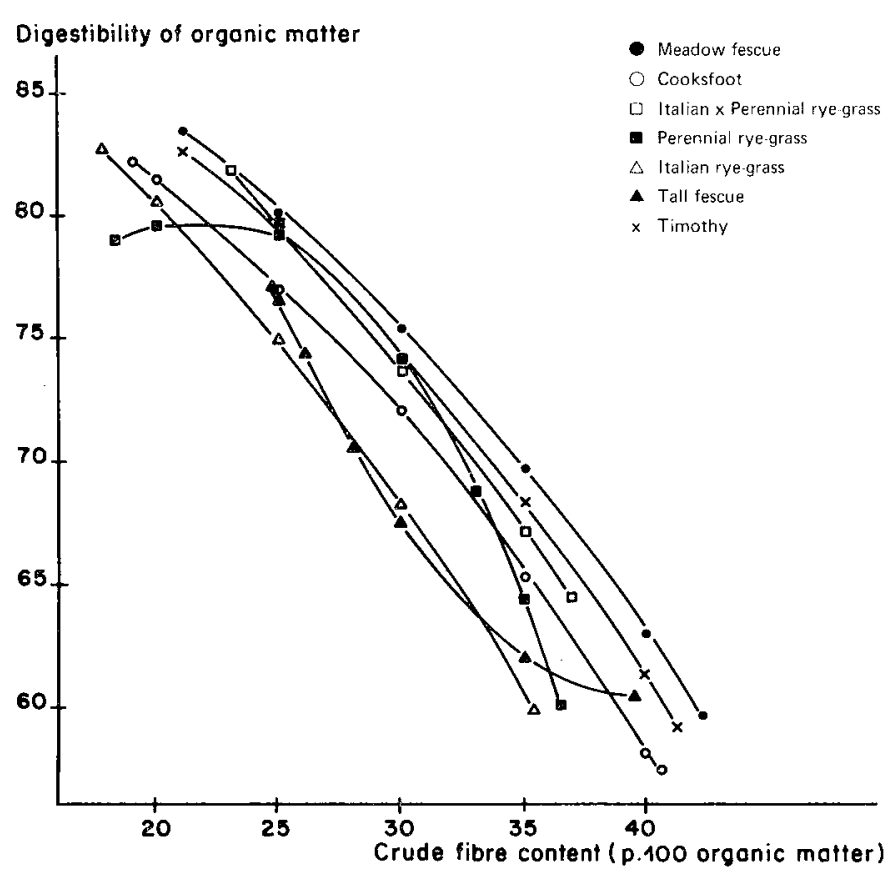

FIG. 2. - Relationships between organic matter digestibility and crude fibre content during 1 st growth of green grasses.

nature of the forage. Only biological methods (in vitro digestibility) make this possible at present. Although biological methods are already in use for this purpose in Great Britain and in Ireland, they are not yet fully available for analytical laboratories, be it only because they require the maintenance of fistulated animals as rumen liquor donors. On the other hand, hopefully, enzymatic methods (digestion in the presence of cellulase) will soon be perfected and will then be used by analytical laboratories.

Lastly, apart from analyses to predict energy and nitrogen values of forages, it may be useful to have an analysis of the conservation qualities of silages when there is reason to believe that they have been poorly conserved (odours, low ingestibility, mediocre animal performances, etc.). In fact, some silages which are rich in ammonia and butyric acid should be fed to animals only in limited quantities, if serious sanitary disturbances are to be avoided.

\section{B. - Concentrated feeds}

\section{1. - Simple feeds}

Energy and nitrogen values of individual concentrate feedstuffs are generally obtained with satisfactory accuracy by referring to Feed Tables. This prediction can be improved if the chemical composition of the food is known (ash, nitrogen. crude fibre, fat). 
1. If the composition is close enough to that of the corresponding feed, quoted in the Tables, organic matter digestibility may be calculated by applying the coefficients of digestibility indicated in the Tables along with the chemical composition data. The energy and nitrogen values may then be computed with the formulae proposed by different countries.

2. When the composition deviates notably, more than one standard deviation for instance, from that of the corresponding feed listed in the Tables, in most cases, the nutritive value can be obtained by extrapolating from the nutritive value (indicated in the Tables) of the various ingredients of the raw material considered, for example, to calculate the nutritive value of a fair soyabean oil meal, by determining from analytical data the respective proportions of soyabean oil meal 48-50 and of soya hulls that compose the oil meal.

In this case, equations that are specific to certain vegetable classes may also be used. Thus, the "Dutch Tables " propose equations to predict the energy value of wheat, maize, cassava and their by-products, from a chemical analysis.

\section{2. - Compound feeds}

Resorting to chemical analysis to control and/or to predict the nutritive value of compound feeds is almost automatic (at least in France) for legislative reasons.

The digestible crude protein may be predicted accurately (the standard deviation of the regression is $<4.5$ per cent) with the formula proposed by SAUVANT (cf. DemarQuilly et al., 1978).

$$
\mathrm{DCP}(\mathrm{g} / \mathrm{kg} \mathrm{OM})=0.914 \mathrm{CP}(\mathrm{g} / \mathrm{kg} \mathrm{OM})-22.3 r=0.997 \text { for } n=61
$$

The PDI content can also be predicted satisfactorily, provided that in addition to the nitrogen and crude fibre contents, the solubility of the feeds nitrogen is known.

SaUvant also proposed formulae for the direct prediction of energy value (in UFL and UFV $/ \mathrm{kg}$ of organic matter) from the nitrogen, crude fibre and fat content in the organic matter. The precision of the prediction is excellent (standard deviation $=0.01 \mathrm{UF} / \mathrm{kg} \mathrm{OM}$ ) for twenty compound feeds not containing ingredients with easily digestible fibre (sugar beet pulp, citrus pulp, soyabean hulls etc.). However, the proposed formulae underestimate the energy value of compound feeds containing concentrate ingredients with easily digestible fibre. Thus incorporating 20 per cent sugar beet pulp into a feed of $0.90 \mathrm{UFL} / \mathrm{kg}$ leads to an underestimate of about $0.04 \mathrm{UFL} / \mathrm{kg}$ when the energy value is to be predicted from the proposed formulae. Furthermore. for these compound feeds, more complex chemical analysis (SAUvant, 1980) should be used, or enzymatic methods, as with certain forages.

\section{Conclusion}

The combined utilisation of the Feed Tables with notes of the growth stage or age that it implies for forages and the proximate chemical analysis, allows for a satisfactory prediction to be made of the nutritive value of feeds, notably 
forages. In practice, it would be useless to expect a very accurate prediction of the nutritive value of forages, since frequently the dry matter intake by animals is only known within 10 to 15 per cent precision. In order to be fully efficient, measures for prediction of forage nutritive value must be organised every year, at the regional level, and must rely on a certain number of reference forages. The results of these reference forages should be made known early in autumn, so they may be used as soon as the animals go inside. At present, the prediction of energy value, based on chemical analysis, remains inaccurate for a certain number of forages, notably for all mixtures. Nonetheless, it may be concluded that for forage mixtures the finalising of enzymatic techniques will allow the prediction of the energy value of these forages to be improved in the near future.

\section{References}

Andrieu J., Weiss P., Doreau B., 1980. Equations proposées pour prévoir la valeur énergétique des fourrages et leur application. In "Prévision de la valeur nutritive des aliments des ruminants" - 11 Journées du Grenier de Theix (in preparation).

Demarquilly C., JARrige R., 1971. The digestibility and intake of forages from artificial and natural grassland. Proc. 4th General Meeting of the European Grassland Federation. Lausanne, 1971. p. 91-106.

Demarquilly C., Weiss P., 1970. Tableaux de la valeur alimentaire des fourrages. INRA, Etude SEI No. 42.

Demarquilly C., 1977. Fertilisation et qualité du fourrage. Fourrages, 69, 61-84.

Demarquilly C., Andrieu J., Sauvant D., 1978. Composition et valeur nutritive des aliments. In INRA 1978 - Alimentation des Ruminants. Ed. INRA Publications (Route de St Cyr) 78000 Versailles. p. 469-518.

Demarquilly C., Grenet E., Andrieu J., 1980. Constituants azotés des fourrages et prévision de la valeur azotée. In "Prévision de la valeur nutritive des aliments des ruminants" - $11^{\mathrm{e}}$ Journées du Grenier de Theix (in preparation).

Deinum B., Van Es A.J.H., Van Soest P.J., 1968. Climate, nitrogen and grass. II - The influence of light intensity, temperature and nitrogen on in vivo digestibility of grass and the prediction of these effects from some chemical procedures. Neth. J. agric. Sci., 16. 217-223.

Minson D.J., McLeod M.N., 1970. The digestibility of temperate and tropical grasses. Proc. XI Int. Grassld Congr., 719-722.

ReYne Y., Garambois X., 1977. Note sur la valeur alimentaire en zone méditerranéenne irriguée du ray-grass d'Italie Tiara et du sainfoin Fakir distribué en vert. Fourrages, 69, $85-96$.

Sauvant D., 1980. La prévision de la valeur énergétique des aliments concentrés et composés. In "Prévision de la valeur nutritive des aliments des ruminants" - II Journées du Grenier de Theix (in preparation). 


\section{Appendix 1}

Method of calculation of the net energy value of feeds, using the new energy systems proposed in France

The net energy (NE) values of feedstuffs are estimated from their gross energy (GE) content, the apparent digestibility of energy $(d \mathrm{E})$, the ratio between metabolisable energy (ME) and digestible energy (DE) contents and the partial efficiency $(k)$ of ME for lactation $(k l)$ and for both maintenance and fattening $(\mathrm{kmf})$.

$$
\mathrm{NE}=\mathrm{GE} \times d \mathrm{E} \times \frac{\mathrm{ME}}{\mathrm{DE}} \times k
$$

\section{Gross energy (GE)}

- For green forages and hays, GE is estimated from the very good relationship observed by DEMARQUILLY et al. (1978) :

$$
\mathrm{Y}=4,531+\Delta+1.735 \mathrm{X} \pm 38 \mathrm{R}=0.945 n=166
$$

where $\mathrm{Y}(\mathrm{kcal} / \mathrm{kg} \mathrm{OM}$ is the GE measured with the calorimetric bomb and X ( N X $6.25 \mathrm{~g} / \mathrm{kg} \mathrm{OM})$ the crude protein content of 166 samples of forages of various origin.

$\Delta=+82$ for permanent pastures and lucerne; for hays of permanent pastures.

$\Delta=-11$ for both fresh herbages such as trefoil, sainfoin, upland permanent pasturcs, whole crop cereals, and for hays from temporary pastures (Italian ryegrass and lucerne).

$\Delta=-71$ for fresh grass such as Italian and perennial ryegrass, tall fescue, etc.

- For other forages, fresh or dried, such as sunflower, cablage, rape, straw, beets and beet pulp, the mean GE values are obtained directly on a small number of samples since their $\mathrm{CP}$ contents vary very little and show no relationship with GE contents.

- The gross energy content of good quality grass silage is estimated using the relationships for green forages. It has in fact been decided to ignore their slightly higher value (3.1 per cent on average) than the corresponding one of green forages since it is not supported by the results of feeding trials.

- The GE of maize silage varies little. The value of $4,560 \div 49 \mathrm{kcal} / \mathrm{kg} \mathrm{OM}$ obtained from 12 representative samples has been retained in the Feed Tables.

- The GE of concentrate feedstuffs has been calculated from the equation proposed by SCHIEMANN et al. (1971):

$$
\mathrm{GE}=5.72 \mathrm{XP}+9.50 \mathrm{XL}+4.79 \mathrm{XF}+4.17 \mathrm{XX}-0.9 \text { per cent }
$$

where $\mathrm{XP}=$ Crude Protein; $\mathrm{XL}=$ Crude Fat; $\mathrm{XF}=$ Crude Fibre; $\mathrm{XX}=$ nitrogen free extract ( $g / k g$ DM).

Energy digestibility $(d E)$ and digestible energy $(D E)$

\section{a) Forages}

Since organic matter digestibility ( $d \mathrm{OM})$, but not $d \mathrm{E}$, had been measured, $d \mathrm{E}$ has been estimated using the following relationship obtained with sheep (DEMARQUILLY et al., 1978):

$$
d \mathrm{E}=1.0087 d \mathrm{OM}-0.0377 \pm 0.007 \quad \mathrm{R}=0.996 n=81
$$

therefore, $\mathrm{DE}=\mathrm{GE}(1,0087 d \mathrm{OM}-0.0377)$.

b) For concentrates, we have used the results of NeHRing et al. (1963):

$$
\begin{array}{ll}
\text { Cereals } & d \mathrm{E}=d \mathrm{OM}-0.013 \\
\text { Oil-cakes } & d \mathrm{E}=d \mathrm{OM}-0.020 \\
\text { Other feeds } & d \mathrm{E}=d \mathrm{OM}-0.015 .
\end{array}
$$




\section{Metabolisable energy (ME)}

ME given in the Feed Tables results from the following calculation:

$$
\mathrm{ME}=\mathrm{DE} \times \frac{\mathrm{ME}}{\mathrm{DE}}
$$

where $\frac{M E}{D E}$ has been calculated from the equation established by VERMOREL and Bouvier:

$\frac{\mathrm{ME}}{\mathrm{DE}}=0.8286-0.0000877 \mathrm{XF}-0.000174 \mathrm{XP}+0.0243 \quad i \pm 0.0093 \quad \mathrm{R}=0.90 \quad n=286$ where $\mathrm{XF}=$ Crude Fibre $(\mathrm{g} / \mathrm{kg} \mathrm{DM}) ; \mathrm{XP}=$ Crude Protein $(\mathrm{g} / \mathrm{kg} \mathrm{DM})$ and $i=$ the level of feeding ( $i=1$ for maintenance).

The level of feeding used in this equation has been the value observed in the digestibility trials for forages, and 1.7 for concentrates and other feedstuffs.

For commercial concentrates, the composition of which is unknown, it is not possible to estimate digestibility and ME content. However SAUvANT (1978) has established a relationship between ME content of mixed concentrates and their chemical composition (XP, XL and XF, g/ $/ \mathrm{kg}$ OM, and $\mathrm{ME}$ in $\mathrm{kcal} / \mathrm{kg} \mathrm{OM}$ ):

$$
\mathrm{ME}=3260+0.455 \mathrm{XP}+3.517 \mathrm{XL}-4.037 \mathrm{XF} \quad \mathrm{R}=0.942 \quad n=61 .
$$

\section{Net energy $(N E)$}

Net energy is the product of ME content by the efficiency $(k)$ of ME for either lactation or for meat production (both maintenance and fattening).

In the new system proposed in France (VERMOREL, 1978), the net energy values are expressed in feed units (FU). One FU is the net energy value of $1 \mathrm{~kg}$ of standard barley which corresponds to the average composition of numerous samples analysed in France between 1970 and 1975.

The net energy for lactation (UFL) is calculated as follows,

$$
\begin{aligned}
& \mathrm{NE}_{l}(\mathrm{Mcal} / \mathrm{kg} \mathrm{DM})=\mathrm{ME}(\mathrm{Mcal} / \mathrm{kg} \mathrm{DM}) \times k^{t} \\
& k_{\iota}=0.60+0.24(q-0.57)\left(\text { where } q=\frac{\mathrm{ME}}{\mathrm{GE}}\right) \\
& \text { Energy value }(\mathrm{UFL})=\frac{\mathrm{ME} \times k_{\imath}}{1.730}
\end{aligned}
$$

The net energy for meat production (UFV) is calculated as follows,

$$
\begin{aligned}
& \mathrm{NE}(\mathrm{Mcal} / \mathrm{kg} \mathrm{DM})=\mathrm{ME}(\mathrm{Mcal} / \mathrm{kg} \mathrm{DM}) \times k_{m f} 1.5 \\
& k m=0.287 q+0.554 \\
& k f=0.78 q+0.006 \\
& k m f=\frac{k m \times k f \times 1.5}{k f+(k m \times 0.5)} \\
& \text { Energy value (UFV) }=\frac{\mathrm{ME} \times \mathrm{kmf}}{1.855}
\end{aligned}
$$

where 1.730 and 1.855 are respectively the NE content of $1 \mathrm{~kg}$ of barley for milk production and for meat production for the level of production of 1.5 .

\section{References}

Demarquilly C., Andrieu J., Sauvant D., 1978. Composition et valeur nutritive des aliments. In : Alimentation des Ruminants, INRA Publications Versailles, 469-518.

Nehring K., Hoffmann L., Schiemann R., Jentsch W., 1963. Die energetische Verwertung der Futterstoffe, 6. Arch. Tierernähr., 13 (3) : 193-213.

Sauvant D., 1978 . Unpublished data.

Schiemann R., Nehring K., Hoffmann L., Jentsch W., Chudy A., 1971. Energetische Futterbewertung der Energienormen. VEB Deutcher Landwirtschafsverlag, Berlin, 344 pp.

Vermorel M., 1978. Energie. In "INRA, Alimentation des Ruminants". INRA Publications Versailles, 48-88.

VERMOREL M., BoUVIER J.C., unpublished data. 


\section{Discussion}

\section{Chair : A. J. H. VAN Es (The Netherlands)}

J.M. Forbes $(U K)$. - Is it not rather negative to say that because we cannot predict intake very accurately at the moment we should not bother too much about nutrient content ? I am sure you were being "Devil's Advocate" in trying to gead us on to better methods of prediction of intake.

C. Demarquilly (France). - In the feed table we give the dry matter intake in feed units for each forage at different stages of growth. It is also possible to estimate the dry matter intake from chemical composition but the work is still in progress. It is possible to estimate with an error of about $5 \mathrm{~g}$ of the dry matter per $\mathrm{kg}$ of metabolic weight from the crude fibre and crude protein content, both for green forage and for cake. It is more complicated for silage because it is necessary to take into account the quality of the conservation.

A.J.H. VAN Es (The Netherlands). - Could one add may be, that if you know digestibility, or you can predict it, for two batches of the same species, the one having a higher digestibility than the other, more will be eaten of the one with the higher digestibility, thus giving you some information on intake, even though you do not know it precisely?

G. Alderman $(U K)$. - I have some sympathy with Dr. Chenost's proposition that too much emphasis on the nutritive value per $\mathrm{kg}$ is a mis-application of what is really required in the on-farm situation. In fact, we are now increasing our emphasis on the necessity to make assessments of dry matter intake in the farm situation. The nutritionist is not doing a particularly good job unless he can do that. For example, with self-feed silage, where there are many variables : the number of animals, the length of chop, the density of the silage, and so on, my staff have been quite successful in estimating likely dry matter intakes in a variety of situations. The other development to which I would draw your attention, and which has been an enormous pleasure to us at the advisory level in the UK, is the introduction of mixer wagons with load cells. We have a new generation of dairy farmers running large dairy herds, who know the dry matter intake of their groups of cattle with a precision of the order of $0.5 \mathrm{~kg} \mathrm{DM} /$ head. This heralds a new era of ration formulation and design. It is only a very small proportion of our dairy farmers, but the situation is perhaps not so bad in the UK as one might imagine. However, we accept your basic point that to formulate rations you do need sound information about dry matter intake, as well as nutritive value $/ \mathrm{kg}$.

\section{A.J.H. VAN Es. - Is it dry matter, or total matter ?}

G. Alderman. - Well, they are recording fresh weights but the uniformity of the dry matter content of their silages, in particular, is such that I think you can put a fairly good degree of precision on their estimates. For good or ill, they will tell you that a particular group of animals is eating $50 \mathrm{~kg}$ of fresh weight and on the information from tables for feeds in equilibrium with air, and for other feeds where they have analyses available, they are able to say that those animals are consuming $19.5 \mathrm{~kg}$ with an energy concentration of $11.4 \mathrm{MJ} / \mathrm{kg}$. I am delighted — it enables one to get to grips with what one is trying to do with much greater precision. It is not the generality but it is happening.

T. Griffiths (Ireland). - I would like to make a comment to Dr. Steg about the situation in Ireland. It is quite right that a very high proportion of roughages which are submitted to our central analytical laboratory are, in fact, assessed for "in vitro" digestibility. I cannot speak about the proportion of the total that are submitted, but of those that are submitted, a large proportion are evaluated. It was suggested in your paper that more use could be made of "in vitro" techniques. Would you are care to enlarge on that ?

A. Steg (The Netherlands). - Dr. Osbourn and Dr. Jarrige have said something about the possibilities of a more accurate prediction of digestibility with "in vitro" procedures. It 
is a matter of opinion as to which type of "in vitro" procedure would be the most interesting. However, I do think that we need to give more emphasis to the routine use of the "in vitro" procedure. After all. the current practice of looking at crude fibre determination is also a time consuming and expensive method which does not always give reliable predictions. I would agreee with Dr. Chenost that it gives good predictions in specific situations, for first cut grass and so on, but not in general. The "in vitro" procedure would be a possibility in general if a satisfactory method of application could be established.

A.J.H. VAN Es. - I think the "in vitro" procedure could better be applied in some areas than others. It would be far too costly to use "in vitro" techniques in the applied work for batches of hay, silage and so on. However, using "in vitro" techniques in such a case to develop regression equations between crude fibre, ADF and digestibility might work out very well. You can do many more "in vitro" tests than "in vivo" tests. With regard to compound feeds, the situation is different. There is still the residual standard error that Dr. Chenost showed, 5.6 or something like that, when a detergent fibre was included. It is still rather high and there I think it is better to use "in vivo".

D.F. Osbourn $(U K)$. - Dr. Chenost said several times that there would be a need to develop local regressions. I would agree with that. In the tabulated prediction of digestibility, how much variation does Dr. Chenost consider is coming in through environmental temperature differences?

M. Chenost (France). - We were talking about specific variability, essentially in nitrogen and mineral content according to location, soil type, fertilisation methods, and so on. However, from the figures proposed in the feed tables and from the regression equations, the precision of estimation of digestibility is fairly good.

Ch. V. Boucque (Belgium). - I just have a small question. In Figure 2 in the paper different species are mentioned - Italian ryegrass, Lolium multiflorum and Lolium perenne, but $I$ do not understand what is meant by Italian $x$ perennial ryegrass.

C. Demarquilly. - It is a hybrid, a cross between Italian and perennial.

H. Bickel (Switzerland). - Coming back to Dr. Steg's question on prediction by chemical composition. We have had some success in the last five or six years in getting the farmers to make their own estimations. Firstly we asked them to take note during the summer time of the stage of maturity and the condition of conservation but mostly they did not do this. However, we have given them tables showing how to do a sensory inspection from the kind of forage, stage of maturity and condition of conservation. What is interesting is that we have found that the precision of the farmers' own estimations is very little less than the precision from the crude fibre estimations with regression coefficients. So in the last three or four years we have pressed them to make these estimations themselves.

R. JARRIGE (France). - I agree with Professor Bickel that our analyses must be complementary to the observations made by the farmer. The second point is that the samples must be taken when cutting the grass. Thirdly, the analyses must be planned at a collective level in a small area. Too much money has been wasted by individual farmers sending a sample of hay or silage to the laboratory and receiving a bad answer three months later.

A. Steg. - Dr. Jarrige said that we need the sample when the grass is cut, but when you are going to predict, let's say, silage from that, if you have very bad weather or bad conservation, then naturally you will run into trouble.

R. JARRIGE. - Yes, but it was stated in the paper that for silages you must have some observations on the fermentation process but for hay, good observation can give the decrease in the nutritive value as well as analysis.

Sir Kenneth Blaxter $(U K)$. - I would like to go back to the question of the concentrated feeds. In our country a very large number of these are put out by commercial firms. It is not only the farmers one has to consider. It is also the compounders who are making these feeds. They wish to know what the nutritive value of their feeds is because they are concerned with selling price and so forth. Now, the equation which Dr. Steg put up is a 
very famous one in our country because it has caused a great deal of trouble insofar as the compounders say that it does not give correct results. They do not only say that it underestimates the value, which is what one might expect, they say that is does not reflect the range in which their compound feedingstuffs fall. After much discussion, we now have an arrangement whereby the Rowett Feedingstuffs Evaluation Unit is taking one year out to determine the nutritive value, by metabolism tests, of a whole series of compound feedingstuffs which have been formulated by a small committee (including Mr. Alderman and the compound feedingstuffs manufacturers) to give the whole of the range in which we think compound feedingstuffs in the UK fall. They are being compounded for us by the feedingstuffs manufacturers and samples of them are being sent to all interested people, so that they can try their own analytical scheme, their own "in vitro" scheme, and so forth. So eventually we will have not only our own analytical data from the Rowett Institute Evaluation Unit,but there will be estimates of nutritive value from everybody else, because the finai valnes, the metabolisable energy, will be made available to everyone. The scheme has now been running for three or four months and will continue for a year, by which time we will have at least a first series of compound feedingstuffs and be able to see if we can get anywhere near firom any attributes that we can measure.

A.J.H. VAN Es. - I wonder if Professor Oslage can tell us anything about the tests which have been made on compound feeds in Germany.

H.J. OsLaGe (Federal Republic of Germany). - Of course, we do have the problem that since a new regulation, although data is known on the composition of the compound feed, it is difficult to make a judgement on the nutritive value. There is a group in Bonn running digestibility trials and then calculating nutritive value from that, but $I$ do not think there is anything very new.

A.J.H. VAN Es. - I believe the experience was that when you published values quoted and values which are actually found in such digestibility trials with sheep, after a few years the two values fitted much better. The compounders have the advantage that they know what they are mixing. "In vitro" digestibility could be a check ; I think the work at present in progress at the Rowett is a very good advance and no doubt they are using "in vitro" to check the "in vivo" results.

Sir Kenneth BLAXTER. - In the course of the digestibility trials each compound is being tested with a hay and a silage at four levels of substitution. So we do get an indication of the validity of any claim that these do bave special effects on the utilisation of roughages, and so on.

D. Sauvant (France). - We tried to test the equations based on proximate analyses on 20 compound feeds. We knew the additive analytic value because we knew the proportions of the ingredients in the feeds. We found a very wide difference in digestibility or energy value. We found a very good fit between the two approaches, the additive approach and the application of our equations based on the proximates analyses. However, there are some problems with compound feeds which include a high level of beet pulp; for example, soyabean hulls, citrus pulp and so on. In France these feeds are called feeds with a high level of digestible cellulose. This is why we tried to apply the method of Van Soest. There is some progress but many problems remain.

\section{R. JARRIGE. - Just as a general remark, what will be the future of crude fibre ?}

Sir Kenneth Blaxter. - Not very much.

R. JARRIGE. - It remains the official method in many countries and a lot of the data in digestibility trials everywhere have been based on crude fibre. So it is not so easy. I recognise that we were conservative in not changing from crude fibre to acid detergent fibre some years ago.

G. Alderman. - We take that point in the UK certainly, both with the Rowett Feed Evaluation Unit and our own Ministry Feed Evaluation Unit, which has been in existence for a rather shorter period of time, with a view to overhauling our own feed tables. I think we have had the Van Soest data from the beginning of both sets of operations precisely for that reason, that it was not reasonable to go ahead. On the other hand you are 
quite right, we have one hundred years of digestibility information only with crude fibre. We are now taking the view, as you are, that we now have to update our tables completely and discard almost entirely the information from the previous century, when we can.

A.J.H. VAN Es. - It would mean discarding a great deal of local information; it is difficult. It would not be so bad if' we could replace crude fibre with a completely satisfactory method, but ADF is not the ultimate answer, maybe it is the first step.

Would you care to comment on this, Sir Kenneth ?

Sir Kenneth Blaxter. - We have know the limitations of crude fibre for a long time. It can be argued that for particular classes of feed, we know sufficient of the crude fibre "art" so that we can interpret it. However, we cannot continue criticising for decade after decade, as we have been doing ever since about 1910, and just keep on using it. We have got to stop sometime.

A.J.H. VAN Es. - I think we are all agreed that the problems is to find an alternative. ADF is not an alternative, but it takes us perhaps 30 per cent of the way along the long road we have to go. It is better defined chemically and physiologically, but it is not the final answer. Perhaps that is a good starting for a workshop on the methodology of analysis of feedingstuffs. 